\title{
ОПРИЛЮДНЕННЯ НОРМАТИВНО-ПРАВОВИХ АКТІВ: ДОСВІД СПОЛУЧЕНИХ ШТАТІВ АМЕРИКИ ТА ВЕЛИКОЇ БРИТАНІЇ
}

Андрусів Л. М.

У статmі проведено аналіз порядку оприлюднення нормативно-правових актів у Сполучених Штатах Америки та Великій Британії. Звернено увагу на техніко-юридичні особливості оприлюднення нормативно-правових актів: форму оприлюднення, засоби офіційного оприлюднення, порядок зберігання оригіналів нормативно-правових актів. 3'ясовано, що офіційне опублікування є формою оприлюднення нормативно-правових актів, а законодавчі акти оприлюднюються в трьох форматах: як окремі закони, збірники законів, які відомі як сесійні закони (United States Statutes at Large), і кодифікований закон, що входить до кодексу (The United States Code). Встановлено, що у Великій Британії як форма оприлюднення використовується офіційне опублікування нормативно-правових актів, а засобами для офіційного оприлюднення в Англії, Шотландії та Північній Ірландії $\epsilon$ газети «London», «Edinburgh», «Belfast». 31798 року нормативно-правові акти публічного права оприлюднюються в серії «Public general acts», натомість акти приватного права - у серії «Local and personal acts».

Ключові слова: англо-американське загальне право, техніко-правова модель оприлюднення нормативно-правових актів, адекватне оприлюднення закону, автентичність оригіналу тексту нормативно-правового акта, умови зберігання тексту закону.

В статье проведен анализ порядка обнародования нормативно-правовых актов в Соединенных Штатах Америки и Великобритании. Обращено внимание на технико-юридические особенности обнародования нормативно-правовых актов: форму обнародования, средства официального обнародования, порядок хранения оригиналов нормативно-правовых актов. Официальное опубликование является формой обнародования нормативно-правовых актов, а законодательные акты обнародуются в трех форма max: как отдельные законы, сборники законов, которые известны как сессионные законы (United States Statutes at Large), и кодифицированный закон, который входит в кодекс (The United States Code). Установлено, что в Великобритании как форма обнародования используется официальное опубликование нормативно-правовых актов, а средствами для официального обнародования в Англии, Шотландии и Северной Ирландии является газеты «London», «Edinburgh», «Belfast». C 1798 года Нормативно-правовые акты публичного права публикуются в серии «Public general acts», а акты частного права - в серии «Local and personal acts».

Ключевые слова: англо-американское общее право, технико-правовая модель обнародования нормативно-правовых актов, адекватное обнародование закона, подлинность оригинала текста нормативно-правового акта, условия хранения текста закона.

The article analyzes the procedure of the promulgation of the normative and legal acts in the USA and Great Britain. The attention is paid to the technical and legal peculiarities of the promulgation of the normative and legal acts in particular: the form of the promulgation, the means of the official promulgation, the order of storing the originals of the normative and legal acts. It is emphasized that the access to the texts of the promulgated normative and legal acts is ensured by placing the texts of the normative legal acts on the official electronic resources. It is stated that after the adoption of the federal laws of the United States and their approval by the President, the originals are sent for the storage by the United States' Archivist. It is found out that the official publication is a form of the promulgation of the normative and legal acts and the legislative acts are promulgated in three formats: as separate laws, as collections of laws known as session laws (United States Statutes at Large) and a codified law included in the code (The United States Code). Legislative acts are prepared for the promulgation by the Federal Register Publications System.

It is established that in Great Britain the Parliament's normative and legal acts are promulgated in the form of the proclamation in the presence of both Houses of Parliament in the House of Lords in the form and in the manner written by the custom: before passing a law or making known to each House of Parliament sitting separately through the speaker of the chamber, and in the absence of the speaker through the person who replaces him. The monarch has the right to declare the king's sanction personally in the Parliament and in the manner in which the law of the Parliament is to be signed on behalf of the monarch. At the same time the official publication of the normative and legal acts is used as a form of the promulgation, and the means of the official promulgation in England, Scotland and the Northern Ireland are the newspapers "London", "Edinburgh", "Belfast". Since 1798, the normative and legal acts of the public law have been promulgated in the series "Public general acts" and the acts of the private law have been promulgated in the series "Local and personal acts".

Key words: English and American common law, technic and legal model of the promulgation of the normative and legal acts, adequate promulgation of the law, authenticity of the original text of the normative and legal act, conditions of the storage of the legal text.

Постановка проблеми та їі актуальність. Оприлюднення нормативно-правових актів $\epsilon$ загальним обов'язковим правилом для національних правових систем. Водночас підходи до правової регламентації цього процесу та форм оприлюднення $\epsilon$ відмінними. Тому для формування ефективної національної правової регламентації та техніко-правової моделі оприлюднення нормативно-правових актів потребує дослідження зарубіжний досвід у вказаній сфері. Установити особливості оприлюднення в певних країнах можна через аналіз практики правового забезпечення та техніки оприлюднення нормативно-правових актів. На актуальність дослідження зарубіжного досвіду також вказує відсутність в Україні наукових розробок у сфері доступу до нормативно-правових актів у зарубіжних країнах. Тому з огляду на потребу формування техніки оприлюднення 
нормативно-правових актів і використання міжнародного досвіду у статті для дослідження обрано досвід оприлюднення нормативно-правових актів у Сполучених Штатах Америки та Великій Британії.

Метою статті $\epsilon$ встановлення порядку, особливостей i правової регламентації оприлюднення нормативно-правових актів у Сполучених Штатах Америки та Великій Британії.

Виклад основного матеріалу. 3 огляду на сталі демократичні традиції та історичні умови формування американського права у юридичній науці та практиці Сполучених Штатів Америки сформувалися дещо інші погляди на оприлюднення нормативно-правових актів.

У дослідженнях оприлюднення нормативно-правових актів у Сполучених Штатах Америки $є$ дві тенденції, які вказують на актуальність правової думки в цій сфері: перша - це зростання кількості правових актів сучасного життя на законодавчому та адміністративному рівнях, що зумовило збільшення кількості й посилення ролі закону, а отже, й активізацію уваги до того, як відповідний закон буде оприлюднено; друга - потреба в усвідомленні адекватного оприлюднення закону з огляду на революцію в комунікаціях та індустрії розповсюдження даних. Демократія передбачає повний доступ громадськості до законотворчого процесу. Однак, як зазначають юристи, це не означає, що урядові органи можуть відкрити законопроєкти для суспільного обговорення, щоб згодом ухвалити закони та інші нормативно-правові акти. Пояснюють це тим, що, відповідно до давнього англо-американського загального права, закон може набрати чинності з моменту його підписання або, якщо це адміністративний акт, може набрати сили відразу після його прийняття, без зобов'язань законодавців оприлюднювати його. Якщо громадянину невідомі норми таких неопублікованих законів, і він порушує їх, то його незнання не гарантує йому жодного юридичного захисту [1].

Окрім того, в американському праві використовують поняття «передчасне набуття публічності» законами. За цим підходом необхідне оприлюднення відбувається під час публічних обговорень законотворців до прийняття законодавчого акта. Однак попереднє опублікування $\epsilon$ лише частковою заміною ефективного оприлюднення. Перший недолік цього підходу полягає в тому, що не все законодавство $\epsilon$ публічним, наприклад, виконавче законодавство може бути висвітлене повністю без попереднього повідомлення, а адміністративне - якщо немає вимог про слухання, передбачених законом. Навіть тоді, коли законодавство $€$ загальнодоступним, публічність не $\epsilon$ спрямованою на сповіщення громадськості. Немає рівномірного та свідомого стандарту, розробленого для процедури оприлюднення. Згенерована суспільством інформація $\epsilon$ випадковим і побічним продуктом політичного процесу. Оскільки законодавча пропозиція не $є$ офіційним актом уряду, то таке оприлюднення акта завжди $\epsilon$ неофіційним [1]. Ключова слабкість підходу передчасного набуття публічності - це той факт, що законопроєкт або запропоноване правило поведінки не має юридичної сили, поки його не ухвалили. Громадськості досить важко не відставати від численних законів, що приймаються кожного року, ніхто не може порахувати точну кількість законопроєктів і запропонованих правил поведінки. Незважаючи на те що попередня публі- кація не $є$ оприлюдненням, вона теж може сприяти процесу оприлюднення.

Щодо самого порядку оприлюднення федеральних законів Сполучених Штатів Америки насамперед виходимо з того, що федеральними $є$ закони, ухвалені Конгресом Сполучених Штатів із (і в деяких випадках без) схваленням Президентом Сполучених Штатів. Установлено, що федеральні законодавчі акти оприлюднюються в трьох форматах: 1) як окремий закон; 2) як збірник законів, що відомі як сесійні закони (United States Statutes at Large) і 3) як кодифікований закон, який входить до кодексу (The United States Code).

Первинне оприлюднення законів здійснюється у формі опублікування закону «як окремих законів» в індивідуальних пазованих буклетах, кожен 3 яких охоплює один закон. Згодом кожного місяця поточні закони публікуються в бюлетені «USCCAN» і перевидаються у вигляді окремих томів після закінчення кожної сесії Конгресу Сполучених Штатів. Бюлетені та томи містять сукупні предметні індекси сесій і таблиць для визначення законів за популярним іменем та частиною кодексу Сполучених Штатів. «USCCAN» доступний у читальному залі юридичної бібліотеки. Крім того, Служба кодексу Сполучених Штатів (USCS) включає щомісячні брошури «USCS Advance», що перевидають чинні публічні закони, які також доступні в читальному залі юридичної бібліотеки. Окрім друкованих джерел, доступних в читальному залі юридичної бібліотеки, будь-хто може знайти ці публікації в юридичних базах за підпискою та в мережі Інтернет. Також у бібліотеці Конгресу Сполучених Штатів можна отримати доступ до законів та статутів за допомогою бази даних, підписавшись на неї, і доступ до USCS на «LexisNexis Library Express» i USCA на «Westlaw», який доступний лише в читальному залі юридичної бібліотеки [2].

Наприкінці року усі акти Конгресу зводяться воєдино і публікуються в хронологічному порядку в черговому номері щорічного видання «Повне зібрання статутів Сполучених Штатів» (United States Statutes at Large), яке $\epsilon$ легальним, офіційним і постійним джерелом усіх законів та сесій Конгресу.

Крім того, положення законів публікуються і в «Кодексі законів Сполучених Штатів» (The United States Code). Особливість цього оприлюднення у тому, що окремі норми законів (а не закони цілком) зводяться за предметом їх регулювання, утворюючи 50 титулів (розділів) кодексу. Кожен титул розділяється на глави і параграфи. До кожного параграфа наведений перелік попередніх нормативно-правових актів. «Кодекс законів Сполучених Штатів» перевидається один раз на шість років, однак щорічно публікуються доповнення, в яких також за титулами фіксуються зміни законодавства за рік. Усі змінипоглинаються черговим виданням зводу [2].

Ці види публікацій законодавчих актів - «первинний закон», «сесійний закон» та «кодифікований закон» доступні в електронних і друкованих джерелах. Норми права у «Повному зібранні статутів Сполучених Штатів» можуть бути знайдені за цитуванням або популярним іменем чи за предметом регулювання, а для швидкого пошуку створено довідковий посібник щодо ресурсів для пошуку статутів.

Кожен закон для опублікування у вигляді окремої брошури систематизує, індексує й публікує у «Повному зібранні статутів Сполучених Штатів» (United States 
Statutes at Large) Федеральний реєстр публікаційних систем Сполучених Штатів (Federal Register Publications System) (OFR). Федеральний реєстр (OFR) присвоює постійний номер закону, юридичну цитату з кожного закону та готує нотатки, цитати й законодавчу історію (короткий опис дій Конгресу за кожним публічним законопроєктом, який також містить дати відповідних заявок або заяв Президента).

Федеральний реєстр (OFR) публікує закони через відділ управління друком у Конгресі Сполучених Штатів та Державну друкарню уряду Сполучених Штатів (GPO). Через Федеральний реєстр законодавчі акти можуть бути отримані як безкоштовні електронні документи з федеральної цифрової системи (FDsys), а також за підтримки уряду США - у паперовому форматі. У паперовому вигляді законодавчі акти США доступні шляхом підписання на сайті або покупки окремої копії від архіватора документів чи в будь-якій федеральній депозитарній бібліотеці [3].

Законопроєкт, розпорядження чи резолюція, що прийняті Сенатом і Палатою представників та затверджені Президентом, якщо він їх не повернув зі своїми запереченнями, стають законом і набувають чинності й повинні бути негайно надіслані архівісту Сполучених Штатів Президентом, Сенатом або спікером Палати представників [4]. Саме на архівіста Сполучених Штатів Америки покладено обов'язок зберігання оригіналів нормативно-правових актів. Як зауважує Л. Левченко, включення Федерального реєстру (OFR) до складу Національного архіву США мало на меті не лише оприлюднення актів, а й надійне зберігання та автентичність їх оригіналів і контрольних примірників друкованих видань [5].

На основі аналізу правової доктрини й правничої практики Сполучених Штатів Америки можна зробити висновок про наявність кількох підходів до сутності оприлюднення нормативно-правових актів. Зокрема, перший підхід полягає у відсутності оприлюднення нормативно-правових актів, другий - у публічному відкритому виданні нормативно-правових актів, третій в оприлюдненні ще проєктів актів, четвертий - в індивідуальному консультуванні кожної зацікавленої людини законодавцем.

Техніку оприлюднення нормативно-правих актів у Сполучених Штатах визначають такі особливості: для оприлюднення нормативно-правових актів використовують дві форми, а саме: офіційне опублікування та електронне оприлюднення; законодавчі акти оприлюднюються через форму опублікування у трьох форматах: як окремі закони, як збірники законів, які відомі у ролі сесійних законів (United States Statutes at Large), i як кодифікований закон, що входить до кодексу (The United States Code); формується та видається повне зібрання законів Сполучених Штатів (United States Statutes at Large) за певний часовий період; специфіка видання «Кодексу Законів Сполучених Штатів» (The United States Code) полягає у тому, що окремі норми законів (а не закони цілком) зводяться за предметом їх регулювання, становлячи 50 титулів (розділів) кодексу; нормативно-правові акти для оприлюднення готує Федеральний реєстр публікаційних систем Сполучених Штатів (Federal Register Publications System); доступ до оприлюднених нормативно-правових актів забезпечується наявністю друкованих засобів оприлюднення актів у читальному залі юридичної бібліо- теки, у бібліотеці Конгресу Сполучених Штатів, а також у мережі Інтернет; формування правил зберігання оригіналів федеральних законів архівістом Сполучених Штатів Америки.

Щодо досвіду у сфері оприлюднення нормативно-правових актів у Великій Британії, то необхідно означити, що англійські підходи до розуміння та тлумачення закону формувалися в контексті ліберальних ідей, прогресивної системи освіти, раціонального державного управління, багатовікової парламентської традиціі. Оприлюднення визначає момент набрання законом чинності і початок його практичної дії. Лише в Англії всі ці акти злиті в одне ціле. Як тільки у парламенті прозвучить оголошення про королівську санкцію білля, він вважається законом, який отримав виконавчу силу й оголошений всім і кожному. Фікція заснована на тому припущенні, що всі англійські піддані представлені в парламенті представниками, отже, те, що сталося і відоме в парламенті, оприлюднено у всій державі. Моментом набрання законом чинності вважається день, зазначений на біллю клерком парламенту, разом з написом про королівську санкцію. Раніше, до кінця минулого століття, діяло більш суворе правило: початком практичної дії закону вважався перший день тієї законодавчої сесії, протягом якої закон виданий. У такому випадку закон мав зворотну силу, а тепер такої не має [6].

щодо набрання нормативно-правовими актами юридичної сили використовуються такі варіанти: акт може набути чинності негайно, з конкретної дати у майбутньому або поетапно. Зацікавлена особа може дізнатися, коли акт набув чи набуває чинності, переглянувши розділ самого нормативно-правового акта, який визначає «Початок дії»- один із останніх розділів акта. Іноді конкретна дата не визначається, а терміни залишаються на розсуд державного секретаря відповідного урядового відомства. Отже, акт може набути чинності за допомогою статутного документа, який називається «Розпорядження про введення в дію» або «Положення про введення в дію» [7].

Оприлюднення нормативно-правових актів у Великій Британії має давні традиції й опирається на правовий звичай, однак все-таки врегульоване на нормативному рівні. На зміст оприлюднення впливає те, що Велика Британія - монархія з тривалими історично обумовленими конституційно-правовими процедурами. Загалом порядок оприлюднення закону у Великій Британії такий: «після схвалення білля обома палатами або подолання заперечень лордів палатою громад, білль направляється на королівську санкцію. Вона дається монархом усно давньофранцузькою мовою». Відповідно до «Royal Assent Act of 1967», «закон парламенту вважається прийнятим належним чином, якщо королівська санкція, підтверджена Патентною грамотою, великою державною печаткою Сполученого Королівства і власноручним підписом монарха, виголошена в присутності обох палат парламенту в палаті лордів у тій формі і тим способом, який встановлений звичаєм, перед прийняттям закону або доведена до відома кожної палати парламенту, що засідають окремо, через спікера палати, а в разі його відсутності - через особу, яка його заміняє. Далі сказано: «Ніщо у цій статті не впливає на право монарха оголосити королівську санкцію особисто в парламенті i в той спосіб, яким закон парламенту повинен бути 
підписаний від імені монарха». Монарх Великої Британії формально володіє правом абсолютного вето, однак із 1707 року (королева Анна не затвердила законопроєкт про створення шотландського ополчення) жоден правитель у цій країні не скористався цим правом. Для всіх законів, ухвалених парламентом, $\epsilon$ обов'язкова формула оприлюднення, текст якої закріплений в «Parliament Act of 1911» (у редакції «Parliament Act of 1949») [8].

Щоб набрати чинності, акт повинен бути опублікований у збірнику законів. До 1798 року публічні та приватні акти публікувалися в одній серії, а з 1798 року вони публікуються в різних серіях. Публічні акти висвітлюються в серії «Public general acts», приватні акти публікуються в серії «Local and personal acts». Канцелярія королеви (Her Majesty's Stationary Office, HMSO) публікує законодавство Великобританії на своєму сайті з 1996 року як королівський публікатор, HMSO контролює опублікування законів, урядових документів, офіційних бюлетенів та ін. Газети «London», «Edinburgh», «Belfast» $€$ офіційними в Англії, Шотландії та Північній Ірландії. Вони видаються приватними компаніями під наглядом HMSO. В Інтернеті представлені сайти (електронні версіі) цих газет. 32000 року все британське законодавство публікується одночасно в друкованому вигляді та на сайті HMSO. 3 жовтня 2002 року ці публікації отримали статус офіційних. Акти парламенту публікуються HMSO на сайті протягом 24 годин після того, як вони були опубліковані в друкованому вигляді [8].

Електронна форма оприлюднення нормативно-правових актів підкріплена наявністю загальнодоступних доменів у мережі Інтернет. До таких джерел загальнодоступного домену належить Управління з питань інформації в громадському секторі (OPSI), яке розміщує законодавчі тексти. Окрім джерел публічного домену для законодавства в мережі Інтернет існує кілька служб передплати. OPSI була створена в 2005 році і взяла на себе функції канцелярії королеви (HMSO).

Доступ до нормативно-правових актів також забезпечується через такі електронні домени: BAILII (Британський та Ірландський інститут правової інформаціі) містить тексти законів з 1988 року та статутних документів з 2002 року; LexisNexis Butterworths - нова платформа, що поєднує послуги Lexis та Butterworths. Він містить ті самі законодавчі дані, що i Lexis Nexis Professional, включаючи статути й анотації Галсбері; статути Justis Великої Британії містять повний текст статутів, прийнятих із посиланням між зміненими та внесеними змінами в законодавство, і $є$ єдиною службою, що охоплює всі скасовані та чинні статути; Westlaw UK (www.westlaw.co.uk або www.westlaw.com) містить укрупнені статути та чинні $\mathrm{Cl}$. На ньому також розмі- щено історичні версії статутів; Lawtel охоплює посилання на офіційну версію законів та статутні таблиці статусу, що містять подробиці змін і доповнень законодавства із посиланнями [9].

На основі проведеного аналізу можна стверджувати, що для техніки оприлюднення нормативно-правових актів у Великій Британії характерні такі особливості: нормативно-правові акти парламенту оприлюднюються шляхом виголошення в присутності обох палат парламенту в палаті лордів у тій формі й тим способом, який встановлений звичаєм, перед прийняттям закону або доведення до відома кожної палати парламенту, що засідають роздільно, через спікера палати, а в разі його відсутності - через особу, яка його заміняє; монарх володіє правом оголосити королівську санкцію особисто в парламенті і тим способом, яким закон парламенту повинен бути підписаний від імені монарха; основним формою оприлюднення нормативно-правових актів $є$ офіційне опублікування. Офіційними засобами для оприлюднення в Англії, Шотландії та Північній Ірландії $\epsilon$ газети «London», «Edinburgh», «Belfast». 31798 року нормативно-правові акти публічного права оприлюднюються в серії «Public general acts», натомість акти приватного права - у серії «Local and personal acts»; нормативно-правові акти доступні в електронній формі на сайті канцелярії королеви (Her Majesty's Stationary Office, HMSO) з 1996 року як королівського публікатора. Канцелярія її Величності (HMSO) контролює опублікування законів, урядових документів, офіційних бюлетенів та ін.

Висновки. На підставі викладеного можемо зробити такі висновки. Для оприлюднення нормативно-правових актів у Сполучених Штатах Америки використовують дві форми, а саме: офіційне опублікування та електронне оприлюднення. Законодавчі акти оприлюднюються через форму опублікування у трьох форматах: як окремі закони, як збірники законів, які відомі у ролі сесійних законів (United States Statutes at Large), і як кодифікований закон, що входить до кодексу (The United States Code). За певний часовий період формується та видається повне зібрання законів Сполучених Штатів (United States Statutes at Large). Основною формою оприлюднення нормативно-правових актів у Великій Британії $\epsilon$ офіційне опублікування. Офіційними засобами для оприлюднення в Англії, Шотландії та Північній Ірландії $\epsilon$ газети «London», «Edinburgh», «Belfast». 31798 року нормативно-правові акти публічного права оприлюднюються в серії «Public general acts», натомість акти приватного права - у серії «Local and personal acts». Окрім того, нормативно-правові акти доступні в електронній формі на сайті канцелярії королеви (Her Majesty's Stationary Office, HMSO). 


\section{Проблеми становлення правової демократичної держави}

\section{Література}

1. Basic Laws and Authorities of the National Archives and Records Administration Book. 2016. URL: https: / / www.archives.gov/files/about/laws/basic-lawsbook-2016.pdf (дата звернення: 05.10.2019).

2. Researching Federal Statutes. URL: https://www.loc. gov/law/help/statutes.php (дата звернення: 25.09.2019).

3. Federal Register Publications System. Public Laws. URL: https://www.archives.gov/federal-register/publications/laws.html (дата звернення: 09.10.2019).

4. Acts and Resolutions; formalities of enactment; repeals; sealing of instruments. URL : https://www.archives.gov/ files/about/laws/basic-laws-book-2016.pdf (дата звернення: 25.10.2019).

5. Левченко Л.Л. Офіційна публікація законів та нормативних актів як функція Національного архіву США. URL:https://archives.gov.ua/Publicat/AU/AU_2_2013/16.pdf.

6. Энциклопедический словарь Ф.А. Брокгауза, И.А. Ефрона.URL: https://dic.academic.ru/dic.nsf/brokgauz_efron/
73809/\%D0\%9E\%D0\%B1\%D0\%BD\%D0\%B0\%D1\%80\%D0\%BE\%D0\% B4\%D0\%BE\%D0\%B2\%D0\%B0\%D0\%BD\%D0\%B8\%D0\%B5 (дата звернення: 13.09.2019).

7. Understanding legislation. URL: http://www.legislation. gov.uk/understanding-legislation\#Howlegislationcomesintoforceandisamended (дата звернення: 16.09.2019).

8. Joseph E. Murphy. The Duty of the Government to Make the Law Known. URL: https://ir.lawnet.fordham.edu/cgi/ viewcontent.cgi?article=4606\& context=flr (дата звернення: 16.09.2019).

9. Carter S. A Guide to the UK Legal System. URL: https: / /www.nyulawglobal.org/globalex/United_Kingdom. html (дата звернення: 16.09.2019).

Андрусів Л. М., кандидат юридичних наук, доцент, професор кафедри соціально-гуманітарних дисциплін Прикарпатського факультету (м. Івано-Франківськ) Національної академії внутрішніх справ 